\title{
Effect of Different Fertilizers (Bio, Organic and Inorganic Fertilizers) on Some Yield Componants of Rice (Oryza Sativa L.)
}

\author{
Gafar Ali Farah", Yassin M. Ibrahim Dagash, Samia Osman Yagoob \\ Department of Agronomy, College of Agric. Studies, Sudan University of Science and Technology (SUST) \\ *Corresponding Author: dagash501@yahoo.com
}

Copyright (C) 2014 Horizon Research Publishing All rights reserved.

\begin{abstract}
A field experiment was conducted at the Demonstration farm of College of Agricultural Studies, Sudan University of science and Technology, in season (2011/2012 and 2012/2013) to study the effect of biofertilizer (EM), organic fertilizer (pellet granule and compost), and inorganic fertilizer (urea + superphosphate), and (urea + superphosphate + compost) on yield components of two varieties of Rice (kosti 1 and omgar). Application of EM gave a positive increase in all of the studied parameters. Moreover, the interaction of EM with kosti 1 gave more significant increments. All treatments have a significant affect compared with control at all parameters studied (spike length $/ \mathrm{cm}$, number of seeds/spike, 1000-seed weight, number of reproductive tillers/plant, yield tons/hectare and harvest index HI). The high yield $2.97 \mathrm{t} / \mathrm{ha}$ was obtained by EM x kosti 1 followed by urea + sup + comp, pellet granule and urea+sup in both season while the control recorded less yield (1.07) t/ha.
\end{abstract}

Keywords Biofertilizer, Compost, Organic Pellet Granule, Productivity, Superphosphate, Urea

\section{Introduction}

Rice (Oryza sativa L.) is the world leading cereal crop for human utilization, with cultivated area of almost 150 million hectares and a total production of almost 600 million mega grams annually (Khush, 2005). It occupies an important place in cereal crops (Irshad et al.,2000). It is a main stable food in the world, especially Southeast Asia's population, who represent two-thirds of the world's population. The world population is expected to reach eight billion by 2030 and Rice production must be increased by $50 \%$ in order to meet the growing demand for the world (Khush and Brar, 2002). In Sudan introduced rice cultivation was introduced since 1906 but stopped for a long period of time (Farah, 1981). In recent ten years many nations entered the Sudan in large numbers from Asia, such as Japanese, Chinese, Bangladeshi, Indian and others to work in oil companies and take with them their food cultures which relied on rice as major food, making the government encourages the cultivation of rice again to fill their need of foods and reduce the import of rice and make it available. Rice in Sudan is grown on 7.60 thousand hectares producing 30 thousand tones. However, Sudan produce an average of $3947 \mathrm{~kg} / \mathrm{ha}$ (AOAD, 2008).

The traditional agriculture predominate in the Sudan, most technical packages and applications of modern agriculture were not known to the farmers, which includes fertilization and plant nutrition, Despite the success, which demonstrated chemical fertilizers to gain increased productivity of many crops, but heavy application of chemical fertilizers may cause negative effects on the environment and the accumulation of certain substances that pollute the soil and discourage some minor elements to be not available to plant; this make alternatives to chemical fertilizers Subject to search and the path of discussion to avoid the negative effects of chemical fertilizers. Among the means available to achieve sustainability in agricultural production, organic manure and bio-fertilizer which play an important and key role because they possesses many desirable soil properties and exerts beneficial effect on the soil physical, chemical and biological Characteristics. However, the most optimum organic and bio-fertilizer doses as well as their effectiveness for upland crops have not been studied in details. In this regard an attempt has been made to study the influence of organic and bio-fertilizer in relation to chemical fertilizers on rice production.

\section{Materials and Methods}

A field experiment was conducted at the demonstration farm of the college of Agricultural Studies, Sudan University of Science and Technology, Shambat, Sudan (latitude $1530^{\prime}$ $\mathrm{N}$ and longitude $3230^{\prime} \mathrm{E}$ ) for two summer seasons 
(2011/2012 and 2012/2013). The soil used in the field investigation was heavy clay, contained $38 \%$ clay, $46 \%$ silt, $16 \%$ sand, $0.12 \%$ total $\mathrm{N}, 7.3 \%$ total $\mathrm{P}, 0.5 \% \mathrm{~K}, 1.6 \%$ O.M (organic matter) and $\mathrm{pH}$ 7.4. Six treatments were tested VIZ. effective microorganisms (EM), Compost, pellet granules manure, urea + superphosphate, and urea + superphosphate + compost and control. Effective microorganisms (EM) are a liquid microbial consortium based on diluted molass. It contains beneficial bacteria and lactic acid. It was obtained from Murroog Company, Khartoum, Sudan. The rate of (EM) was 15 liters/ha added by dropping in the water with irrigation until the harvest. The seeds were mixed until completely coated before sowing. Seeds were sown and immediately irrigated after sowing. Compost was added to the soil at the rate of 15 tons /ha at a week before sowing. The pellet granules manure, obtained from Thailand, is organic manure added at a rate of $50 \mathrm{~kg} / \mathrm{ha}$. Urea and superphosphate were added at the rate of $83 \mathrm{~kg} \mathrm{~N} / \mathrm{ha}, 50 \mathrm{~kg} / \mathrm{ha}$ respectively in addition to their combinations. The Control was kept for comparison. Two release varieties Kosti 1 and Umgar were obtained from the Agricultural Research Corporation, Wad Medani, Sudan. The Land was prepared by ploughing, harrowing and then leveling. It was divided into plots $(3 \times 3$ $\mathrm{m}^{2}$ ) each. The experiment was arranged in spilt plot with a randomized complete block design (RCBD) with four replicates. The measured parameters were, Number of productive tillers/plant, Unproductive tillers/plant Number of seeds/spike, Number of spikelet's/spike, spike length in $\mathrm{cm}$, Number of leaves/plant, leaf area in $\mathrm{cm}, 1000$-seed weight/g and productivity tons/ha at harvest, one meter square was randomly chosen from the internal rows of each plot and manually harvested to determine seed yield/plot. The data were subjected to analysis of variance using MSTAT.C program and LSD test means separation.

\section{Results}

\subsection{Spike Length (cm)}

The results presented in Table 1 showed that all treatments recorded significant $(\mathrm{p} \leq 0.05)$ differences in spike length $(\mathrm{cm})$ of Rice compared with control plants in both seasons. The treatment pellet granules record highest spike length in both season, followed by EM, urea+sup, compost, urea + sup + compost.

\subsection{Number of Seeds/Spike}

All fertilization treatments increased the number of seeds per spike compared to the control plants, in particular the fertilizer EM in both season (Table 1). The highest significant $(p \leq 0.05)$ mean in number of seeds per spike was obtained by the application of EM, compost and urea + sup + compost in both seasons.

\section{Reproductive Tillers}

Table 2 showed that all treatments increased reproductive tillers per plant compared to the control plant in plants in both season. The highest and significant $(\mathrm{p} \leq 0.05)$ increments in productive tillers were obtained by the application of EM with variety kosti 1 in season one, but in season 2 the highest increment was obtained by treatment (urea + sup + comp) compared to other treatments.

\subsection{0-seed Weight (g)}

All the tested treatments increased the 1000-seed weight compared to the control plants in both seasons as cleared in Table 2 . There were highly significant differences $(p \leq 0.05)$ among treatments and interaction in the analysis of variance. The highest increments were obtained by EM with the variety kosti 1 in both seasons.

\subsection{Yield Tons/Hectare}

A positive effect of the fertilization treatments on yield was showed in Table 3. The yield ranged between 1.07 and 2.97 ton/ha in the first season and 1.39 and 2.95 in the second season (Table 3). Application of EM gave the highest and significant $(\mathrm{p} \leq 0.05)$ increment on yield in the first season compared with control, but in the second season the treatment (urea+sup+comp) recorded highest increment, followed by EM, compost, pellet granules, and (urea+sup).

\subsection{Harvest Index}

All fertilization treatments increased the percentage of harvest index compared to control in both season (Table 3). The highest percentage counted by the treatment EM with the variety kosti 1 followed by compost, pellet granule and (urea + sup + comp) in the first season and (urea + sup + comp), (uera+sup). Pellet granule and compost in the second season. 
Table 1. Effect of biofertilizer, organic fertilizers and inorganic fertilizers on spike length (cm)\& number of seeds/spike

\begin{tabular}{|c|c|c|c|c|c|}
\hline \multirow{2}{*}{ Varieties } & \multirow{2}{*}{ Treatment } & \multicolumn{2}{|c|}{ spike length $(\mathrm{cm})$} & \multicolumn{2}{|c|}{ number of seeds/spike } \\
\hline & & $2010 / 2011$ & $2011 / 2012$ & $2010 / 2011$ & $2011 / 2012$ \\
\hline \multirow{6}{*}{ Kosti 1} & Em & $13.3^{\mathrm{E}}$ & $19.0^{\mathrm{e}}$ & $49.3^{\mathrm{B}}$ & $52.2^{\mathrm{a}}$ \\
\hline & compost & $11.7^{\mathrm{D}}$ & $18.8^{\mathrm{ef}}$ & $50.7^{\mathrm{B}}$ & $41.2^{\mathrm{d}}$ \\
\hline & pellet granules & $11.1^{\mathrm{D}}$ & $17.7^{\mathrm{g}}$ & $29.0^{\mathrm{DE}}$ & $43.4^{\mathrm{c}}$ \\
\hline & Urea + sup + comp & $11.1^{\mathrm{D}}$ & $18.6^{\mathrm{f}}$ & $26.8^{\mathrm{E}}$ & $45.9^{\mathrm{b}}$ \\
\hline & Urea+sup & $11.7^{\mathrm{D}}$ & $19.7^{\mathrm{d}}$ & $31.4^{\mathrm{D}}$ & $41.3^{\mathrm{d}}$ \\
\hline & Control & $7.4^{\mathrm{E}}$ & $17.8^{\mathrm{g}}$ & $21.7^{\mathrm{F}}$ & $33.5^{\mathrm{h}}$ \\
\hline \multirow{6}{*}{ Omgar } & Em & $14.8^{\mathrm{B}}$ & $20.6^{\mathrm{c}}$ & $56.2^{\mathrm{A}}$ & $40.8^{\mathrm{de}}$ \\
\hline & compost & $13.16^{\mathrm{C}}$ & $21.6^{\mathrm{a}}$ & $40.0^{\mathrm{C}}$ & $36.6^{\mathrm{g}}$ \\
\hline & pellet granules & $16.5^{\mathrm{A}}$ & $20.9^{\mathrm{b}}$ & $31.2^{\mathrm{D}}$ & $38.9^{\mathrm{ef}}$ \\
\hline & Urea + sup + comp & $13.3^{\mathrm{C}}$ & $21.4^{\mathrm{a}}$ & $40.2^{\mathrm{C}}$ & $38.7^{\mathrm{f}}$ \\
\hline & Urea+sup & $15.3^{\mathrm{AB}}$ & $21.1^{\mathrm{b}}$ & $37.5^{\mathrm{C}}$ & $42.5^{\mathrm{cd}}$ \\
\hline & Control & $8.3^{\mathrm{E}}$ & $20.6^{\mathrm{c}}$ & $17.5^{\mathrm{G}}$ & $32.0^{\mathrm{h}}$ \\
\hline \multicolumn{2}{|c|}{ L S D } & 1.28 & 0.344 & 2.66 & 2.043 \\
\hline \multicolumn{2}{|c|}{$\mathbf{C V}$} & $25 \%$ & $6.55 \%$ & $17.76 \%$ & $12.08 \%$ \\
\hline
\end{tabular}

Means followed by the capital letters are not significantly different at first season, while the means followed by small letters are not significantly different at second season at $5 \%$ level using LSD.

Table 2. Effect of biofertilizer, organic fertilizers and inorganic fertilizers on reproductive tillers \& 1000-seeds weight (g).

\begin{tabular}{|c|c|c|c|c|c|}
\hline \multirow{2}{*}{ Varieties } & \multirow{2}{*}{ Treatment } & \multicolumn{2}{|c|}{ reproductive tillers } & \multicolumn{2}{|c|}{1000 -seeds weight $(\mathrm{g})$} \\
\hline & & $2010 / 2011$ & $2011 / 2012$ & $2010 / 2011$ & $2011 / 2012$ \\
\hline \multirow{6}{*}{ Kosti 1} & Em & $20.75^{\mathrm{a}}$ & $11.90^{\mathrm{E}}$ & $29.20^{\mathrm{b}}$ & $26.80^{\mathrm{A}}$ \\
\hline & Compost & $12.63^{\mathrm{de}}$ & $10.80^{\mathrm{FG}}$ & $22.40^{\mathrm{e}}$ & $25.50^{\mathrm{B}}$ \\
\hline & pellet granules & $14.45^{\mathrm{b}}$ & $11.45^{\mathrm{EF}}$ & $24.25^{\mathrm{d}}$ & $24.63^{\mathrm{C}}$ \\
\hline & Urea + sup + comp & $13.23^{\mathrm{cd}}$ & $13.15^{\mathrm{D}}$ & $29.70^{\mathrm{a}}$ & $26.00^{\mathrm{B}}$ \\
\hline & Urea+sup & $15.18^{\mathrm{b}}$ & $11.45^{\mathrm{ef}}$ & $24.20^{\mathrm{d}}$ & $26.00^{\mathrm{B}}$ \\
\hline & Control & $9.23^{\mathrm{g}}$ & $10.55^{\mathrm{G}}$ & $22.35^{\mathrm{e}}$ & $21.92^{\mathrm{D}}$ \\
\hline \multirow{6}{*}{ Omgar } & Em & $12.07^{\mathrm{ef}}$ & $14.30^{\mathrm{BC}}$ & $24.67^{\mathrm{c}}$ & $17.88^{\mathrm{H}}$ \\
\hline & Compost & $14.55^{\mathrm{bc}}$ & $15.15^{\mathrm{ab}}$ & $20.20^{\mathrm{h}}$ & $18.25^{\mathrm{GH}}$ \\
\hline & pellet granules & $11.77^{\mathrm{ef}}$ & $14.10 \mathrm{c}$ & $21.90^{\mathrm{f}}$ & $19.63^{\mathrm{E}}$ \\
\hline & Urea + sup + comp & $12.63^{\mathrm{de}}$ & $16.00^{\mathrm{a}}$ & $20.50^{\mathrm{g}}$ & $19.50^{\mathrm{E}}$ \\
\hline & Urea+sup & $11.58^{\mathrm{f}}$ & $14.35^{\mathrm{BC}}$ & $24.60^{\mathrm{c}}$ & $18.88^{\mathrm{F}}$ \\
\hline & Control & $8.96^{\mathrm{g}}$ & $10.05^{\mathrm{G}}$ & $20.30^{\text {gh }}$ & $18.50^{\mathrm{FG}}$ \\
\hline \multicolumn{2}{|r|}{ L S D } & 1.05 & 0.881 & 0.288 & 0.520 \\
\hline \multicolumn{2}{|r|}{ C V } & $19.20 \%$ & $16.54 \%$ & $2.91 \%$ & $5.68 \%$ \\
\hline
\end{tabular}

Means followed by the capital letters are not significantly different at first season, while the means followed by small letters are not significantly different at second season at $5 \%$ level using LSD. 
Table 3. Effect of biofertilizer, organic fertilizers and inorganic fertilizers on yield ton/ha and harvest index.

\begin{tabular}{|c|c|c|c|c|c|}
\hline \multirow{2}{*}{ Varieties } & \multirow{2}{*}{ Treatment } & \multicolumn{2}{|c|}{ yield ton/ha } & \multicolumn{2}{|c|}{ harvest index } \\
\hline & & $2010 / 2011$ & $2011 / 2012$ & $2010 / 2011$ & $2011 / 2012$ \\
\hline \multirow{6}{*}{ Kosti 1} & Em & $2.97^{\mathrm{a}}$ & $2.95^{\mathrm{A}}$ & $14.35^{\mathrm{b}}$ & $14.24^{\mathrm{A}}$ \\
\hline & compost & $2.03^{\mathrm{c}}$ & $2.05^{\mathrm{G}}$ & $9.24^{\mathrm{c}}$ & $10.40^{\mathrm{D}}$ \\
\hline & pellet granules & $186^{\mathrm{c}}$ & $2.48^{\mathrm{C}}$ & $7.02^{\mathrm{f}}$ & $10.58^{\mathrm{D}}$ \\
\hline & Urea + sup + comp & $2.26^{\mathrm{b}}$ & $2.57^{\mathrm{C}}$ & $7.53^{\mathrm{ef}}$ & $12.89^{\mathrm{B}}$ \\
\hline & Urea+sup & $1.90^{\mathrm{c}}$ & $2.32^{\mathrm{D}}$ & $7.75^{\mathrm{def}}$ & $11.71^{\mathrm{C}}$ \\
\hline & Control & $1.18^{\mathrm{e}}$ & $1.39^{\mathrm{H}}$ & $3.27^{\mathrm{h}}$ & $8.18^{\mathrm{E}}$ \\
\hline \multirow{6}{*}{ Omgar } & Em & $2.46^{\mathrm{b}}$ & $2.82^{\mathrm{B}}$ & $20.63^{\mathrm{a}}$ & $8.15^{\mathrm{E}}$ \\
\hline & compost & $2.00^{\mathrm{c}}$ & $2.19^{\mathrm{EF}}$ & $14.78^{b}$ & $7.10^{\mathrm{F}}$ \\
\hline & pellet granules & $1.47^{\mathrm{d}}$ & $2.08^{\mathrm{FG}}$ & $9.44^{\mathrm{c}}$ & $8.23^{\mathrm{E}}$ \\
\hline & Urea + sup + comp & $2.05^{\mathrm{c}}$ & $2.27^{\mathrm{DE}}$ & $8.53^{\text {cde }}$ & $8.00^{\mathrm{E}}$ \\
\hline & Urea+sup & $1.96^{\mathrm{c}}$ & $2.30^{\mathrm{DE}}$ & $8.67^{\mathrm{cd}}$ & $8.67^{\mathrm{E}}$ \\
\hline & Control & $1.07^{\mathrm{e}}$ & $2.00^{\mathrm{G}}$ & $5.18^{\mathrm{g}}$ & $5.38^{\mathrm{G}}$ \\
\hline \multicolumn{2}{|c|}{ L S D } & 0.206 & 0.121 & 1.097 & 0.716 \\
\hline \multicolumn{2}{|c|}{$\mathrm{CV}$} & $25.60 \%$ & $12.56 \%$ & $27.12 \%$ & $18.14 \%$ \\
\hline
\end{tabular}

Means followed by the capital letters are not significantly different at first season, while the means followed by small letters are not significantly different at second season at $5 \%$ level using LSD.

\section{Discussion}

It is clear from data presented in Table 1, 2 and 3, that application of biofertilizer and organic fertilizers increased most of the studied parameters. Similar results were founded by Harish et al., (2010), Dash et al.,(2010).In the present study, application of EM showed significant increase in all studied parameters. This could be attributed to the availability of soil microorganisms that are able to convert the unavailable forms of nutrients elements to available from (Saber, 1994). The inorganic fertilizers urea and superphosphate also increased significantly some studied parameters (productive tillers, 1000-seed weight and yield) compeered with control. This may be due to soil deficiency to nitrogen and available phosphorus and competition of weeds. Similar results were obtained by Ishsya and Dauda (2010).

\section{Acknowledgments}

We gratefully acknowledge the Staff of Department of Agronomy College of Agriculture studies Sudan University for their help during fieldwork. The study was funded by Deanship of Research, Sudan University of Sciences and Technology.

\section{REFERENCES}

[1] Dash D, Hrusikesh P, Ramesh C, Tiwari and Mohamed S,(2012). The effect of organic and inorganic source of nitrogen on yield attributes, grain yield and straw yield of Rice. Research Journal of Agronomy 4(2): 18-23.

[2] Irshad, A., G.H. Abbas, A. Khaliq, (2000). Effect of different Nitrogen application Techniques on the Yield and Yield Components of Fine Rice. International journal of agricultural \& biology, 02-3 239-241.

[3] Ishaya D B and Dduda S N.(2010). Evaluation of nitrogen fertilization and Herbicides on lowland Rice in Nigeria. American - Euvasion jornalof Sustainable Agriculture, 4(1): 14-19.

[4] Harish H. Deshpande and Devasenapathy P. (2010). Effect of green manure and organic manure on yield, quality and economics of Rice under low land condition. Karnataka. Agri. Sci., 23(2): (235-238).

[5] Khush G S (2005). What it will take to feed 5.0 billion rice consumers by 2030.Plant Mol. Biol. 59:16.

[6] Khush G S and Brar DS (2002). Biotechnology for Rice breeding: progress and impact. In: Sustainable Rice production for food security. Proceed. 20th Session Int. Rice Comm. pp. 23-26.

[7] Saber M S M (1994). Bio-organic farming systems for sustainable agriculture.

[8] Inter-Islamic Network on Genetic Engineering and Biotechnology, INOGE Publ.3, Cairo, Egypt. 